Karaman, G. (2021): The Genus Turcogammarus G. Karaman \& Barnard 1979 (fam. Pontogammaridae) in monastery Hilandar region (Greece) (Contribution to the knowledge of the Amphipoda 323). Agriculture and Forestry, 67 (4): 141-164. doi:10.17707/AgricultForest.67.4.13

DOI: $10.17707 /$ AgricultForest.67.4.13

\author{
Gordan S. KARAMAN ${ }^{1}$
}

\title{
THE GENUS TURCOGAMMARUS G. KARAMAN \& BARNARD 1979 (FAM. PONTOGAMMARIDAE) IN MONASTERY HILANDAR REGION (GREECE) (CONTRIBUTION TO THE KNOWLEDGE OF THE AMPHIPODA 323)
}

SUMMARY
First member of freshwater Crustacea Amphipoda, Turcogammarus spandli S. Karaman, 1931 (Fam. Pontogammaridae), is discovered and described from the region of Monastery Hilandar on Mount Athos on Halkidiki peninsula, northern Greece. This species is redescribed, figured and variability of its taxonomical characters are given. The review of all known members of genus Turcogammarus G. Karaman \& Barnard, 1979 and key to the species of this genus are presented. Taxonomical position of genus Turcogammarus within family Pontogammaridae is discussed.

Keywords: taxonomy, Amphipoda, Pontogammaridae, Turcogammarus spandli, freshwater, Hilandar Monastery, Greece

\section{INTRODUCTION}

Hilandar Monastery is one of the twenty Eastern Orthodox monasteries on Mount Athos in northern Greece, and the only Serbian monastery there. It was founded in 1198 by Stefan Nemanja (Saint Symeon) and his son Saint Sava. It is situated on northern side of Mount Athos, on Athos peninsula of Halkidiki peninsula, Aegean Sea, Northern Greece. This monastery has strict tradition that bars women from stepping into Mount Athos. As this part of Halkidiki peninsula is practically isolated and needs the permissions to visit them, the biodiversity of this region is poorly known.

The fauna of Amphipoda of entire Mount Athos was never studied. During my visit to monastery Hilandar in September 1996 with some other Academicians of Academy of Sciences and Arts of Montenergo and Academy of Sciences and Arts of Serbia, I have a short opportunity to collect the amphipods from the brook near Monastery, presented in this work.

\footnotetext{
${ }^{1}$ Gordan S. Karaman (corresponding author: karaman@t-com.me), Montenegrin Academy of Sciences and Arts, Podgorica, MONTENEGRO.

Notes: The author declares that he has no conflicts of interest. Authorship Form signed online. 


\section{MATERIAL AND METHODS}

The material was preserved in $70 \%$ ethanol. The specimens were dissected using a WILD M20 microscope and drawn using a camera lucida attachment. All appendages were temporarily submersed in a mixture of glycerin and water for study; dissected body-parts were fixed in Liquid of Faure and covered by thin cover glass.

Some morphological terminology and setal formulae follows Karaman`s terminology (Karaman G., 1969) for mandibular palpus article 3 [A= A-setae on outer face; $\mathrm{B}=\mathrm{B}$-setae on inner face; $\mathrm{C}=$ additional submarginal $\mathrm{C}$-setae on outer face; $\mathrm{D}=$ lateral marginal $\mathrm{D}$-setae; $\mathrm{E}=$ distal long E-setae]. All illustrations were inked manually.

Term "setae" and "spines" are used based on its shape, not origin. The investigations were provided based on morphological, ecological and zoogeographical studies.

\section{TAXONOMICAL PART}

\section{Order AMPHIPODA \\ Suborder SENTICAUDATA \\ Family PONTOGAMMARIDAE Bousfield, 1977}

Genus TURCOGAMMARUS Karaman, G. \& Barnard, J.L., 1979: 137

Typus generis: Turcogammarus turcarum (Stock, 1974).

Species: Turcogammarus aralensis (Uljanin, 1875), setosus (Schäferna, 1914), spandli (S. Karaman, 1931), turcarum (Stock, 1974).

\section{TURCOGAMMARUS SPANDLI (S. Karaman, 1931) \\ Figures 1-8}

Ostiogammarus spandli S. Karaman, 1931: 45, fig. 2; S. Karaman, 1934:

219; S. Karaman, 1953: 49, 57;

Dikerogammarus spandli Birstein, 1945: 519, 520; Carausu, Dobreanu \& Manolache, 1955: 54; Barnard, J.L., 1958: 48; Straškraba, M., 1967: 204;

Pontogammarus spandli Schellenberg, 1937: 267; Karaman, G., 1971:

36, figs. 39-55;

Obesogammarus spandli Stock, 1974: 83;

Turcogammarus spandli Karaman, G. \& Barnard, J.L., 1979: 137;

Barnard, J.L. \& Barnard, C.M.1983: 170; Sket \& Hou, 2018: suppl. 2: 6 . 


\section{MATERIAL EXAMINED: GREECE:}

S-5422= Monastery Hilandar, Halkidiki peninsula, Agio Oros, Mt.

Athos, torrent near Monastery, 24.9.1996, many exp. mixed with one juv. exp. Niphargus sp. (leg. G. Karaman);

S-1439= Volvi Lake, $60 \mathrm{~km}$ E of Thessaloniki, coast, northern Greece, 24.4.1962, 14 exp. (leg.?Kosswig);

S-1454= Drama, spring "Varvara", northern Greece, many exp., 20.10.1942 (leg. Buresch);

S-4200= Drama, 20.10.1942, 9 exp. (leg.?);

G-266= Greece 266, loc?, 6 exp. (leg. ? K. Lindberg);

SLIDES: holotype, Dervent near Thessaloniki, northern Greece.

\section{DIAGNOSIS OF SPECIES}

Body moderately stout, mesosomal segments flat or last mesosomal segment with dorsal longitudinal elevation or tooth; metasomal segments 1-3 with more or less developed dorsomedian elevation obtusely triangular or toothed (hooked). Urosomal segments 1-2 with dorsomedian tubercle bearing spines and setae; urosomal segment 3 flat, with dorsolateral groups of elements (spines and setae) and dorsomedian surface with 2 short setae. Telson incised nearly to the basis. Epimeral plate 1 nearly subrounded, epimeral plates 2-3 pointed, all plates setose. Antenna 1 shorter, peduncle inflated, accessory flagellum 3-4-articulated. Antenna 2 remarkably setose, flagellum longer than last peduncular article; eyes reniform.

Mouthparts nearly Gammarus-like, labium without inner lobes. Mandible palpus 3-articulated, with A, C, D and E-setae. Maxilla 1 palpus left and right asymmetric; Maxilla 2 inner plate with marginal and submarginal row of setae; maxilliped plates obtuse distally, palpar article 4 with slender spines at inner margin. Coxae 1-4 long, coxa 4 with ventroposterior lobe, coxae 5-7 much shorter than coxae 1-4, bilobed. Gnathopods 1-2 dissimilar, with Gammarus-like propodus bearing median palmar spine in males; dactylus of pereopods 3-7 with one inner marginal seta near basis of the nail.

Pereopods 3-4 similar, densely setose, pereopod 4 smaller than 3 . Pereopods 5-7 dissimilar: article 2 of pereopods 5 and 7 lobed, that of pereopod 6 unlobed, all with densely setose posterior margin of article 2 and bearing facial setae. Pleopods with 2 retinacula, peduncles remarkably setose. Uropod $1 \mathrm{rami}$ equal, uropod 2 inner ramus longer than outer one. Uropod 3 inner ramus short; outer ramus 2-articulated, densely setose, second article very short. Telson incised nearly to the basis. Sexual dimorphic characters developed.

\section{DESCRIPTION}

MALE $12.8 \mathrm{~mm}$ [Hilandar]: Body moderately stout, mesosomal segments smooth; metasomal segments 1-3 with dorsomedian longitudinal subrounded carina more or less elevated in the middle (fig. 1B). Urosomal segments 1-2 with dorsomedian tubercles provided with 2 spines and 6-7 setae as 
long as or longer than spines; urosomal segment 3 flat, provided on each dorsolateral side with group of 3 strong spines and 3 setae (fig. 1C), in the middle of segment 3 appears 2 short setae (1C). Urosomal segment 1 without ventroposterior spine near basis of uropod 1-peduncle but with one bunch of short ventromarginal setae (fig. 1C).

Epimeral plate 1 nearly subrounded, with poorly marked ventroposterior corner-seta; anterior and ventral margin with numerous simple setae, along posterior convex margin with row of shorter setae (fig. 4A). Epimeral plates 2-3 strongly pointed; epimeral plate 2 with row of ventral long setae and row of shorter posterior marginal setae; outer surface covered with bunches of facial setae. Epimeral plate 3 less setose than plate 2, along ventral margin with row of single or paired longer setae, along posterior margin with row of several shorter setae; facial setae absent (fig. 4A).

Head with short rostrum and angular lateral cephalic lobes, ventroanterior sinus well developed; eyes reniform, as long as or slightly longer than diameter of first peduncular article of antenna 1 (fig. 1A).

Antenna 1 almost reaching half of body-length; peduncular articles 1-3 progressively shorter (ratio: 52:30:20); first article inflated, longer than broad (ratio: 52:25), bearing 2-3 bunches of distal setae not exceeding diameter of article itself (fig. 1E); article 2 slightly tapering distally, bearing distal and several lateral setae (the longest setae exceeding diameter of article itself); article 3 narrowed, with 2 lateral and 2 distal bunches of setae (the longest setae exceeding diameter of article itself). Main flagellum rather longer than peduncle, with 20 slender articles bearing short marginal setae. Accessory flagellum 4-articulated, longer than last peduncular article of antenna 1 (fig. 1E).

Antenna 2 moderately slender, nearly as long as antenna 1 (in living animals); peduncular article 3 short, rather inflated, provided with ventrodistal bunch of long setae and 2 bunches of short dorsal setae (fig. 1F). Peduncular articles 4-5 of nearly equal length; article 4 ventral margin with 2 groups of setae longer than diameter of article itself, dorsal margin with 5 bunches of short setae; article 5 ventral margin with 4 bunches of long setae (the longest setae exceeding diameter of article itself), dorsal margin with 3 bunches of shorter setae. Flagellum relatively slender, 10-articulated, nearly as long as peduncular articles 4-5, dorsal margin with bunches of short setae, ventral margin with bunches of long setae much longer than diameter of article itself; calceola absent; antennal gland cone short (fig. 1F).

Mouthparts nearly Gammarus-like. Labrum broader than long, tapering distally (fig. 2A). Labium broader than long, outer lobes subrounded distally, inner lobes absent (fig. 2B).

Mandibles with triturative molar. Left mandible: incisor with 5 teeth, lacinia mobilis with 4 teeth accompanied laterally by 8 strong rakers (fig. 2D). Right mandible with 4-toothed incisor, lacinia mobilis bifurcate, serrate, accompanied by 7 rakers (first raker rather shorter and less pectinate than other rakers (fig. 2C). 


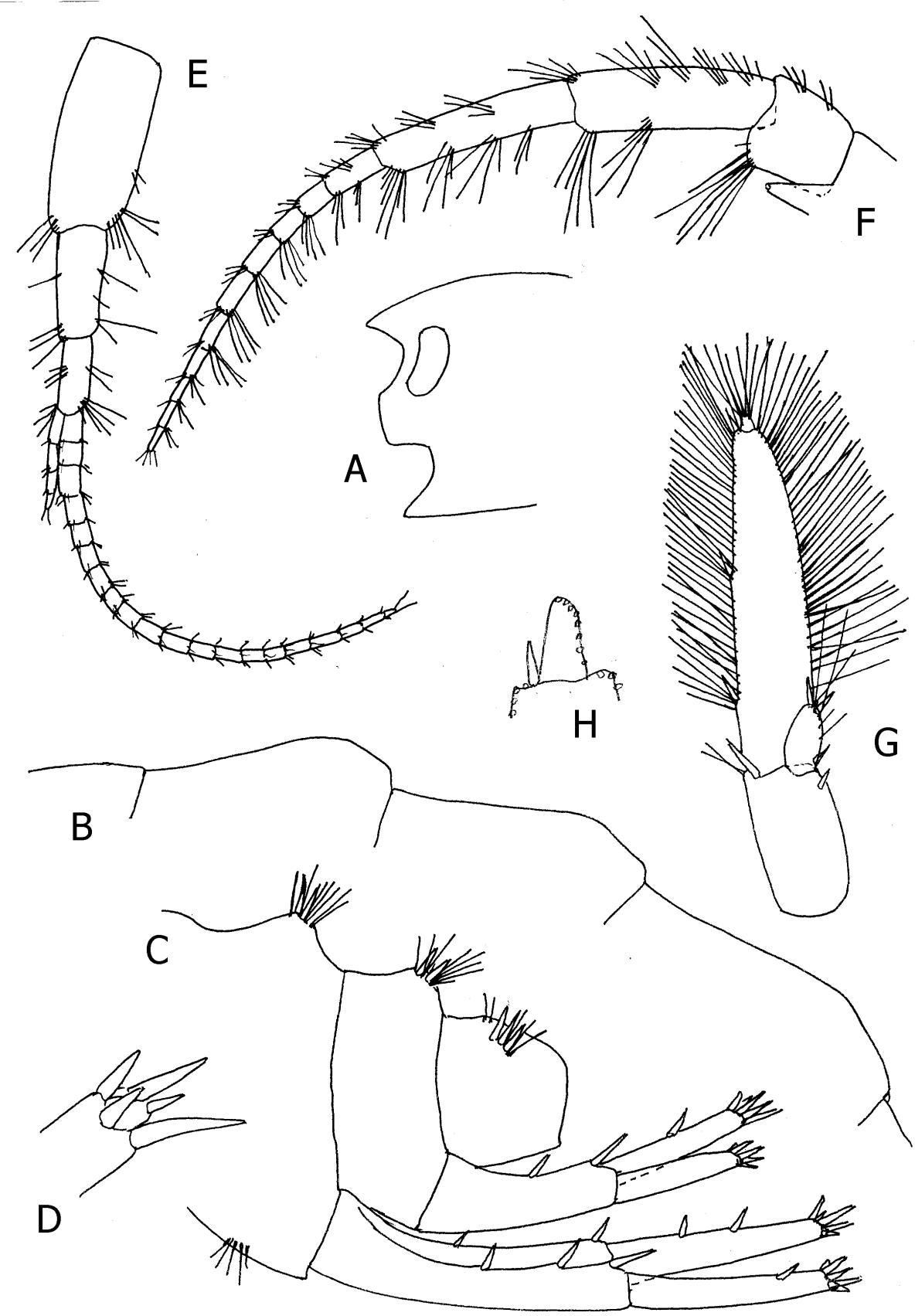

Fig. 1. Turcogammarus spandli (S. Karaman, 1931), torrent near Hilandar Monastery, male $12.8 \mathrm{~mm}: \mathrm{A}=$ head; $\mathrm{B}=$ metasomal segments $1-3 ; \mathrm{C}=$ urosome with uropods $1-2 ; \mathrm{D}=$ tip of uropod 2 inner ramus; $\mathrm{E}=$ antenna $1 ; \mathrm{F}=$ antenna 2; $\mathrm{G}=$ uropod 3 (all setae plumose); $\mathrm{H}=$ distal article of uropod 3 outer ramus (setae omitted). 


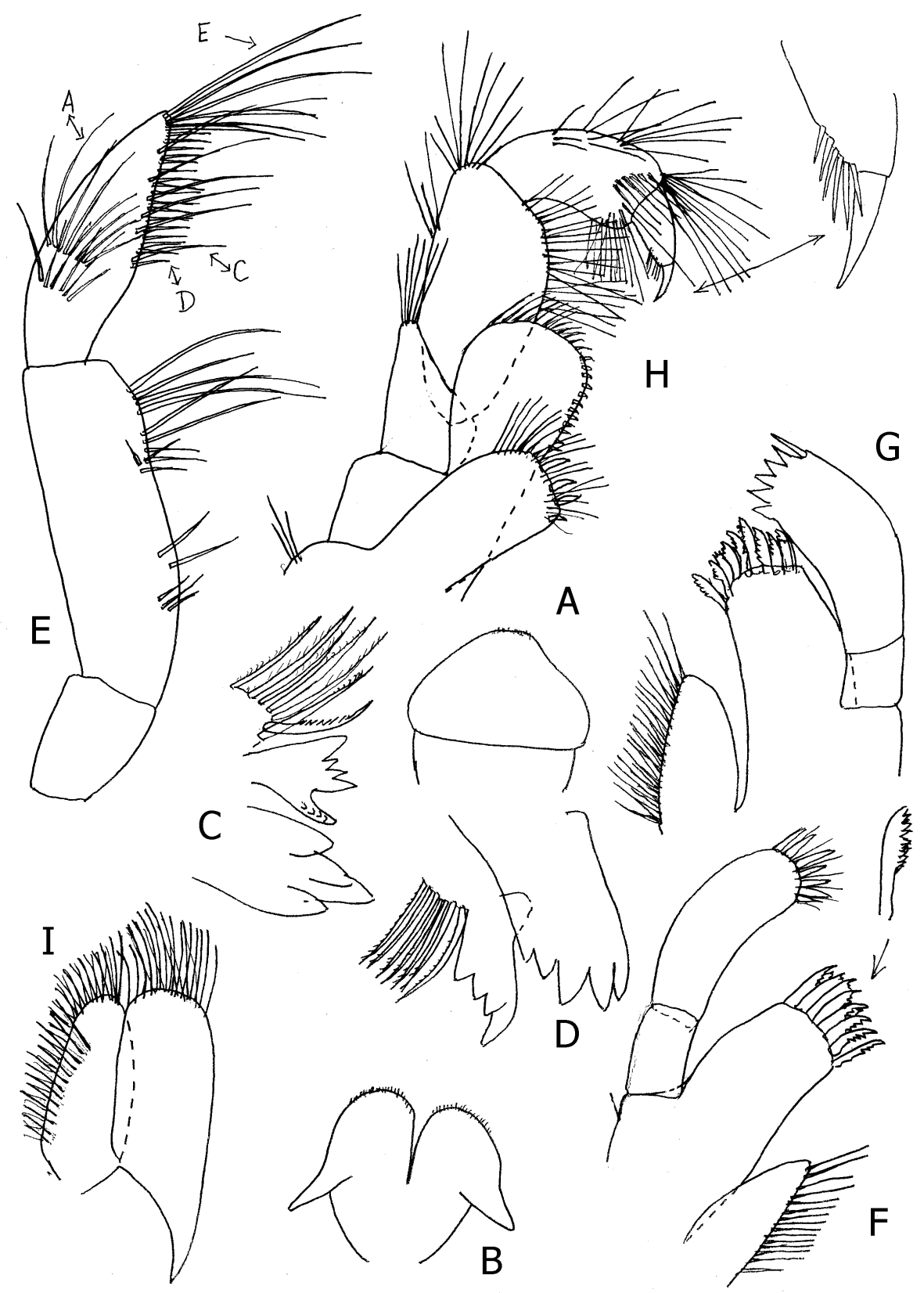

Fig. 2. Turcogammarus spandli (S. Karaman, 1931), torrent near Hilandar Monastery, male $12.8 \mathrm{~mm}$ : $\mathrm{A}=$ labrum; $\mathrm{B}=$ labium; $\mathrm{C}=$ right mandible, incisor and lacinia mobilis with rakers; $\mathrm{D}=$ left mandible, incisor and lacinia mobilis with rakers; $\mathrm{E}=$ mandibular palpus, outer face $[A=$ outer facial $A$-setae; $C=$ outer facial submarginal $C=$ setae; $D=$ marginal D-setae; $\mathrm{E}=$ distal E-setae $; \mathrm{F}=$ left maxilla $1 ; \mathrm{G}=$ right maxilla $1 ; \mathrm{H}=$ maxilliped; I= maxilla 2; 
Palpus similar in both mandibles, 3-articulated: first article naked; second article with nearly 16 strong setae; third (distal) article poorly shorter than second one, subfalciform, with nearly 20 marginal D-setae, 6 submarginal C-setae and 67 distal long E-setae (fig. 2E); on outer face 2 transverse rows of A-setae (14 setae) (fig. 2E), B-setae absent.

Left maxilla 1: inner plate triangular, with row of marginal setae at mesial side; outer plate with nearly 9-10 pectinate spines; palpus more narrow, with 5 spines mixed with 5-6 stronger setae (fig. 2F). Right maxilla 1: inner and outer plate like these in left maxilla; palpus broader, with 5 distal strong teeth and one corner spine (fig. 2G).

Maxilla 2: both plates longer than broad, with subrounded distal margin; inner plate slightly smaller than outer one, along mesial margin with 2 rows of setae (marginal and submarginal), distal margin of both plates with numerous setae (fig. 2 I).

Maxilliped: inner plate short and broad, not reaching outer tip of first palpus article, provided with 4 distal spines mixed with several short setae and several setae at distoexternal tip (fig. $2 \mathrm{H}$ ). Outer plate strong, broad, not exceeding half of second palpus article, at mesial margin with row of short spines, at tip with several spine-like setae. Palpus article 2 at outer margin with 2 bunches of long setae, inner margin with row of numerous long setae; palpus article 3 outer margin with 4 bunches of longer setae, inner margin with numerous distointernal and distal setae; article 4 (dactylus) outer margin with one median short seta, inner margin with 5 slender spines behind nail (fig. $2 \mathrm{H}$ ).

Coxae 1-4 relatively long. Coxa 1 longer than broad (ratio: 70:40), poorly dilated distally, subrounded distal margin with numerous long setae (fig. 3A). Coxa 2 longer than broad (ratio: 73:42), tapering ventrally, ventral subrounded margin with numerous long setae (fig. 3D). Coxa 3 much longer than broad (ratio: 82:42), slightly tapering distally, ventral subrounded margin with numerous setae (fig. 4B). Coxa 4 longer than broad (ratio: 80:60), ventral convex margin almost straight in the middle, with numerous long setae, ventroposterior lobe well developed (fig. 4D).

Coxae 5-7 much shorter than coxae 1-4, bilobed, ventral margin subrounded. Coxa 5 broader than long (ratio: 50:35), anterior narrowed lobe with 2-3 distal setae, posterior lobe with 5-7 marginal strong setae (fig. 5A).

Coxa 6 smaller than coxa 5, broader than long (ratio: 45:27), anterior lobe with bunch of marginal setae, posterior lobe with row of strong marginal setae (fig. 5B).

Coxa 7 shallow, much broader than long (ratio: 44:23), anterior lobe small, with one lateral bunch of setae, posterior larger lobe with numerous strong marginal setae (fig. 5C).

Gnathopod 1 rather smaller and unequal than gnathopod 2; article 2 posterior margin with long setae, anterior margin with longer and shorter setae. Article 3 with distoposterior bunch of setae (fig. 3A). Article 5 triangular, much shorter than propodus (ratio: 28:49), anterior margin with distal setae, posterior 
margin with numerous setae. Propodus slightly egg-shaped, longer than broad (ratio: 113:58), posterior margin with 6 transverse rows of setae, anterior margin scarcely setose, with distal setae (fig. 3B). Palm inclined almost to the half of propodus-length, irregularly serrate, without distinct medial excavation, outer face with 3-4 corner and one median palmar spine mixed with several long setae, on inner face 2 subcorner short R-spines (fig. 3C). Dactylus with one median seta at outer margin (fig. 3B), and 2-3 short setae near nail.

Gnathopod 2: article 2 posterior margin with row of long setae, several proximal setae at anterior margin; median and distal part with row of short setae; article 3 with distoposterior bunch of setae. Article 5 much shorter than propodus (ratio: 32:65), posterior margin with bunch of distoanterior setae and numerous setae (fig. 3D). Propodus remarkably longer than broad (ratio: 120:77), with nearly parallel lateral margins, posterior margin with nearly 11 transverse rows of setae, only single setae at anterior margin and bunch of shorter distal setae (fig. $3 \mathrm{E})$. Palm inclined nearly $2 / 5$ of propodus-length, irregularly serrate, defined on outer face by 3-4 corner single spines mixed with single setae, and one median palmar spine mixed with several long setae, on inner face by 2 short subcorner Rspines (fig. 3F). Dactylus with one median seta at outer margin (fig. 3E) and 1-2 setae near nail.

Pereopods 3-4 moderately stout. Pereopod 3: article 2 anterior margin with proximal long and distal shorter setae, posterior margin with several bunches of long setae; article 3 anterior margin with bunch of median setae and distoposterior bunch of distal setae (fig. 4B). Articles 4-6 of different length (ratio: 45:33:37): article 4 with slightly produced anterior tip, and with 4 anterior marginal bunches of long setae; posterior margin with numerous long setae (the longest setae exceeding diameter of article itself). Article 5 with distoanterior long setae and 4 posterior marginal bunches of long setae. Article 6 with 2 bunches of anterior marginal shorter setae, posterior margin with 7 single short spine mixed with single longer setae (the longest setae exceeding diameter of article itself). Dactylus shorter than article 6 (ratio: 15:37), strong, with one strong seta at inner margin and one slender lateral seta near basis of nail (fig. 4C), nail shorter than pedestal (ratio: 21:34).

Pereopod 4 rather similar to pereopod 3 but slightly smaller; article 2 pilosity like that in pereopod 3; article 3 with 1-3 short anterior and posterior median marginal setae and bunch of long posterior distal setae. Articles 4-6 of different length (ratio: 38:30:33). Article 4 distoanterior tip slightly produced, 3 bunches of anterior marginal setae (fig. 4D), posterior margin with 4 bunches of long setae (the longest setae exceeding diameter of article itself). Article 5 with anterodistal longer setae, posterior margin with nearly 4 bunches of long setae (longer than diameter of article itself). Article 6 anterior margin with 2 bunches of setae, posterior margin with 7 single short spines mixed with single long setae. Dactylus shorter than article 6 (ratio: 15:33), inner margin with setae like these in pereopod 3. 

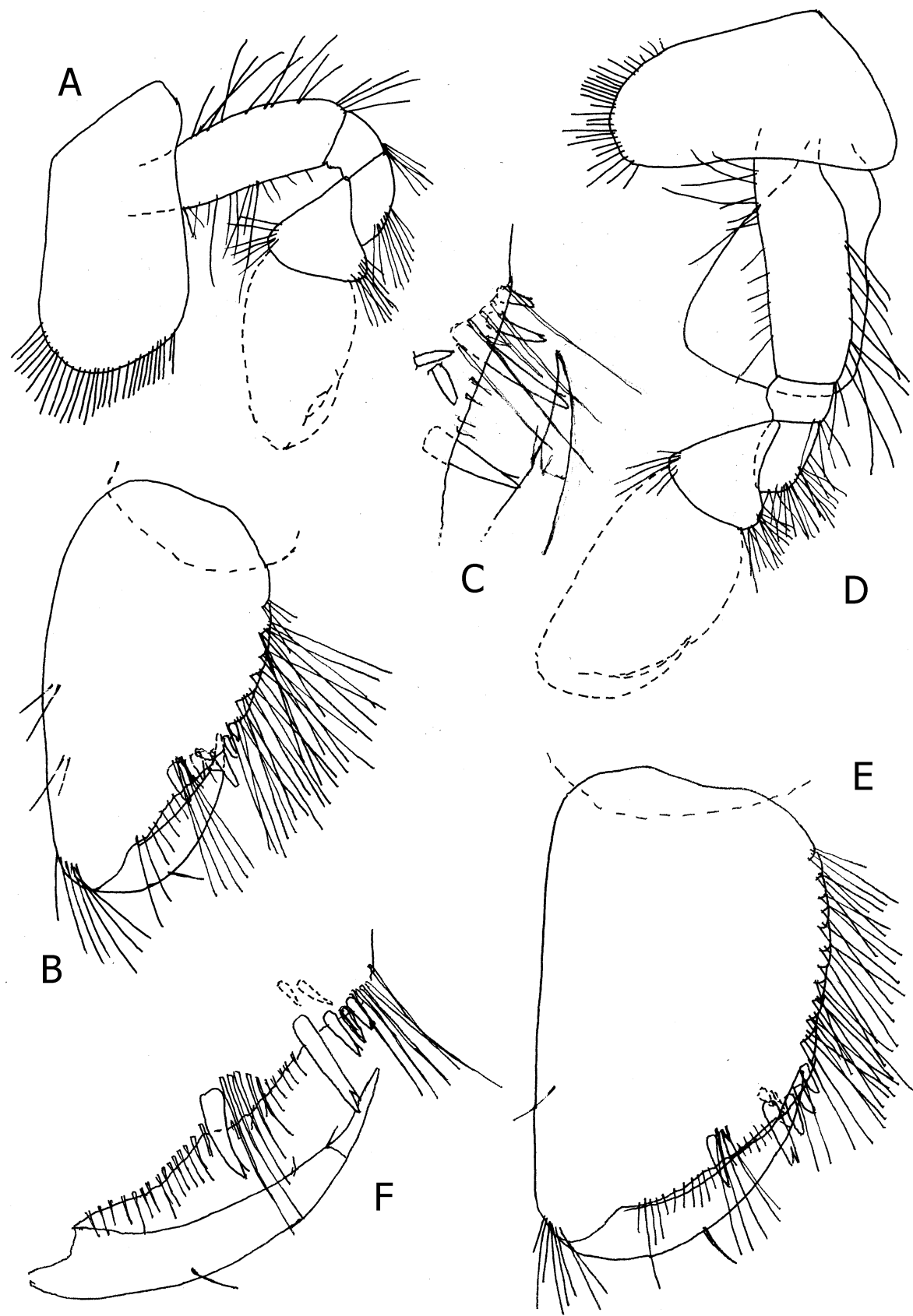

Fig. 3. Turcogammarus spandli (S. Karaman, 1931), torrent near Hilandar Monastery, male $12.8 \mathrm{~mm}$ : A-B= gnathopod 1, outer face; $\mathrm{C}=$ distal corner of gnathopod 1-propodus, inner face; $\mathrm{D}-\mathrm{E}=$ gnathopod 2, outer face; $\mathrm{F}=$ distal corner of gnathopod 2-propodus, outer face. 


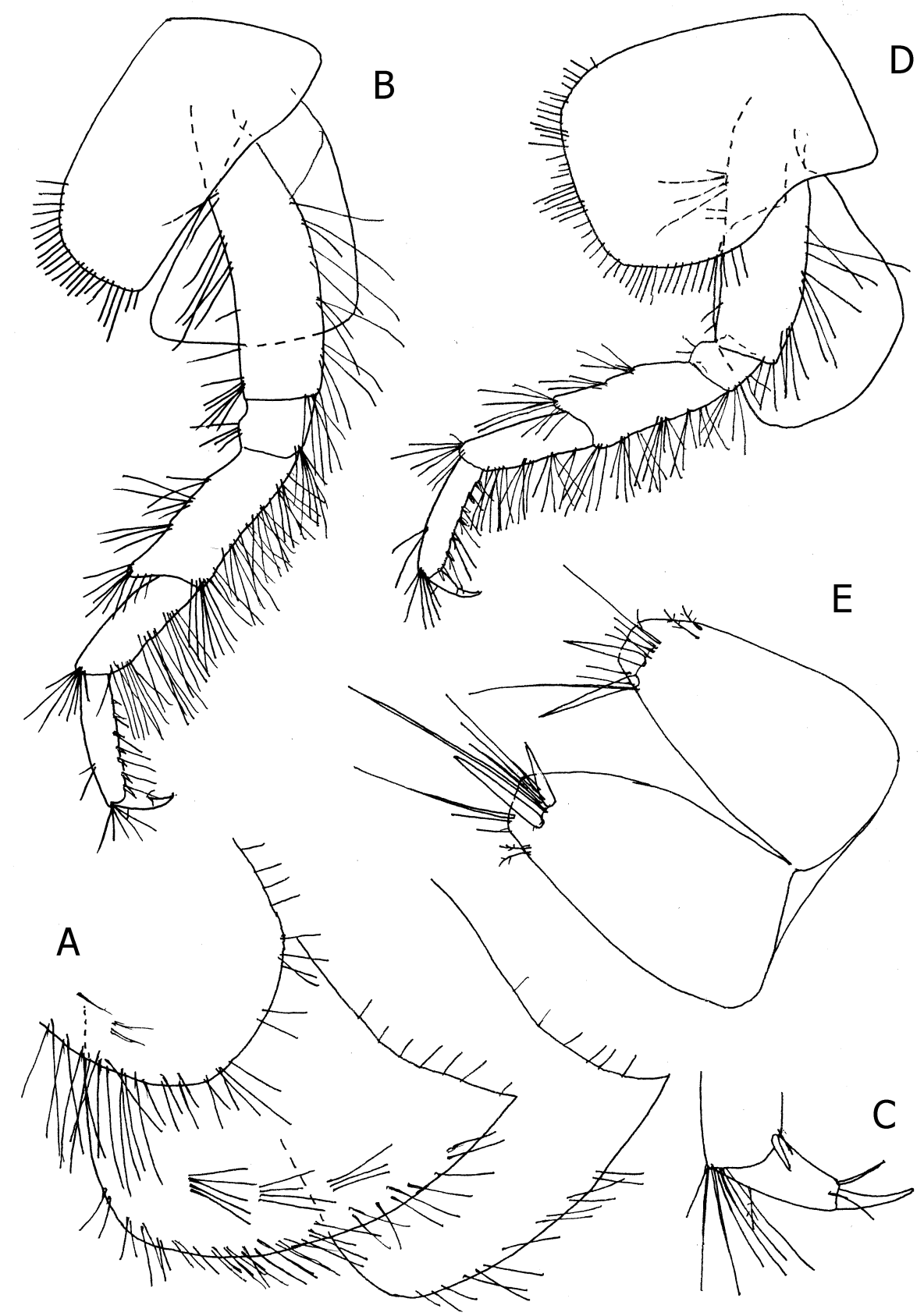

Fig. 4. Turcogammarus spandli (S. Karaman, 1931), torrent near Hilandar Monastery, male $12.8 \mathrm{~mm}$ : $\mathrm{A}=$ epimeral plates $1-3 ; \mathrm{B}-=$ pereopod $3 ; \mathrm{C}=$ dactylus of pereopod 3; $\mathrm{D}=$ pereopod 4; $\mathrm{E}=$ telson. 
Pereopods 5-7 moderately stout. Pereopod 5 slightly shorter than pereopods 6-7: article 2 dilated, longer than broad (ratio: 65:23), anterior convex margin with 5-6 single spines mixed with setae as long as or longer than spines, posterior crenulated margin straight in the middle, with row of densely sitting setae, ventroposterior lobe visible; inner face with groups of setae, outer face naked (fig. 5A). Article 3 with anterior distal setae, posterior margin naked. Articles 4-6 of different length (ratio: 40:47:51); article 4 anterior margin with 3 median bunches of setae (most of them as long as diameter of article itself) and distal bunch of setae mixed with one spine (the longest setae exceeding diameter of article itself); posterior margin with 3 groups of spines and setae; article 5 along anterior margin with 3 bunches of long setae and spines, at posterior margin 2 bunches of setae and single spines. Article 6 anterior margin with 6 pairs of short spines often mixed with single seta, posterior margin with 4 bunches of long setae. Article 6 shorter than article 2 (ratio: 51:65). Dactylus much shorter than article 6 (ratio: 20:51) with pilosity like that of pereopod 7 .

Pereopod 6 slightly longer than pereopod 5. Article 2 longer than broad (ratio: 77:45), tapering ventrally, outer and inner surface with numerous single or bunches of setae; anterior margin with 6 single spines mixed with several setae each, 2 bunches of setae in proximal part; posterior crenulated margin with dense row of longer setae, ventroposterior lobe absent (fig. 5B). Article 3 with anterodistal setae, posterior margin with bunch of median setae. Articles 4-6 of different length (ratio: 45:57:60); articles 4 and 5 along anterior margin with 4-5 bunches of longer setae (the longest setae exceeding diameter of article itself); article 4 with 2 posterior bunches of setae mixed with single spines; article 5 at posterior margin with median bunch of longer setae and distal setae and spines. Article 6 anterior margin with 6 single of paired short spines and 5 bunches of longer posterior setae. Article 2 shorter than article 6 (ratio: 77:60). Dactylus shorter than article 6 (ratio: 20:60), its pilosity like that in pereopod 7 .

Pereopod 7 rather different than pereopods 5-6; articles 4-6 shorter than these in pereopod 6. Article 2 longer than that of pereopods 5-6, large, ovoid, longer than broad (ratio: 88:57), with well developed ventroposterior subangular lobe (fig. 5C), anterior margin with 6 single spines mixed with several setae usually longer than spines; 2-3 bunches of setae in proximal part; posterior convex, finely crenulated margin with dense row of longer setae (fig. $5 \mathrm{~F}$ ); outer face with row of 7-9 bunches of setae (fig. 5C), on inner face appear several groups of 1-3 setae (fig. 5D). Article 3 with distoanterior and medioposterior setae. Articles 4-6 of different length (ratio: 47:50:57). Articles 4-5 with 4 groups of anterior spines mixed with long setae, posterior margin with 2 bunches of setae and single spines. Article 6 with 6 single or paired short anterior spines, posterior margin with 5 bunches of long setae. Article 6 remarkably shorter than article 2 (ratio: 57:88). Dactylus shorter than article 6 (ratio: 20:57), strong, inner margin with long seta, one lateral seta near basis of nail, outer margin with one median plumose seta (fig. 5E), nail shorter than pedestal (ratio: 23:48). 


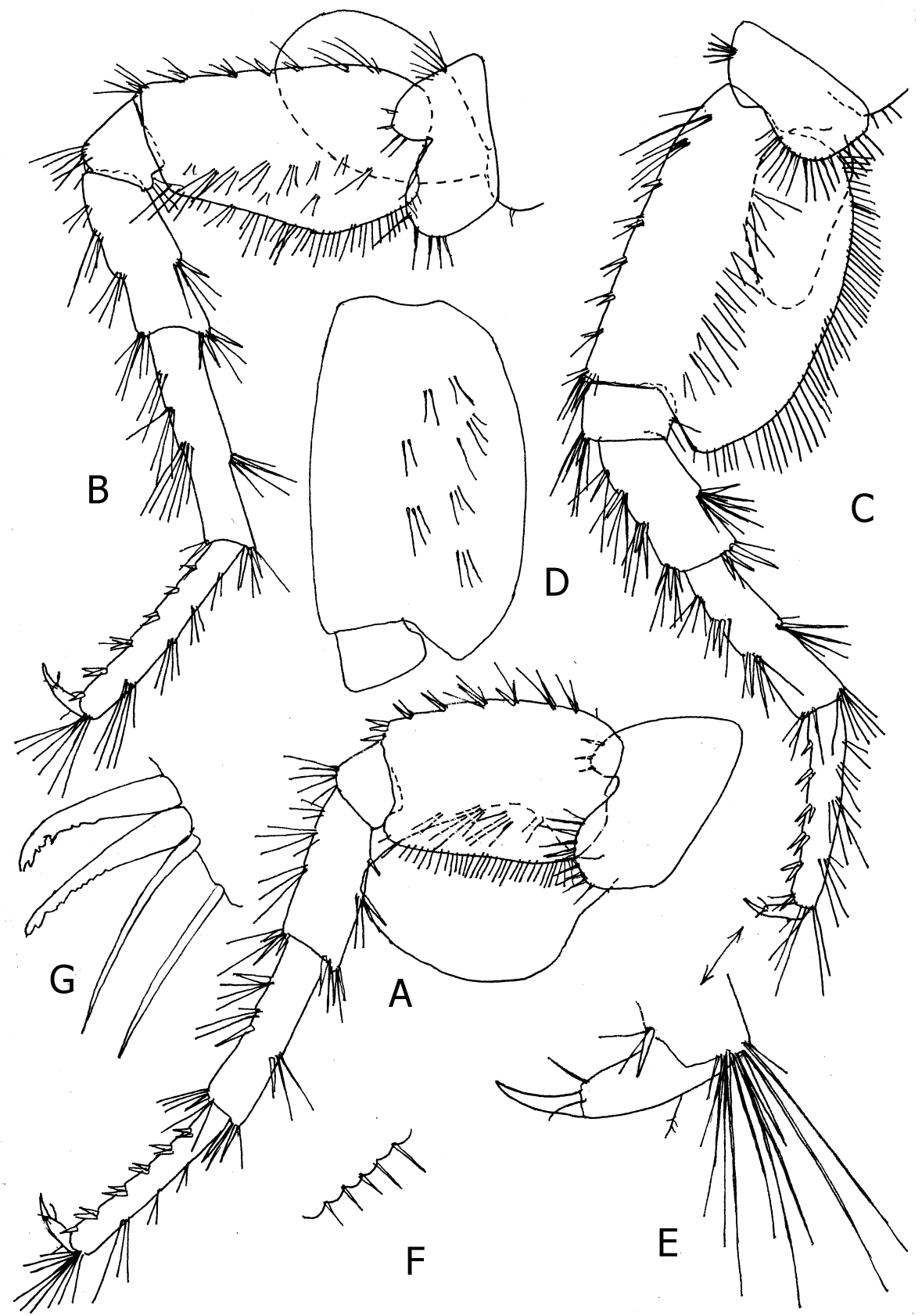

Fig. 5. Turcogammarus spandli (S. Karaman, 1931), torrent near Hilandar Monastery, male $12.8 \mathrm{~mm}$ : $\mathrm{A}=$ pereopod 5, outer face; $\mathrm{B}=$ pereopod 6 , outer face; $\mathrm{C}=$ pereopod 7 , outer face; $\mathrm{D}=$ article 2 of pereopod 7, inner face (marginal setae omitted); $\mathrm{E}=$ pereopod 7 dactylus; $\mathrm{F}=$ posterior margin of pereopod 7 article 2; $\mathrm{G}=$ retinacula. 


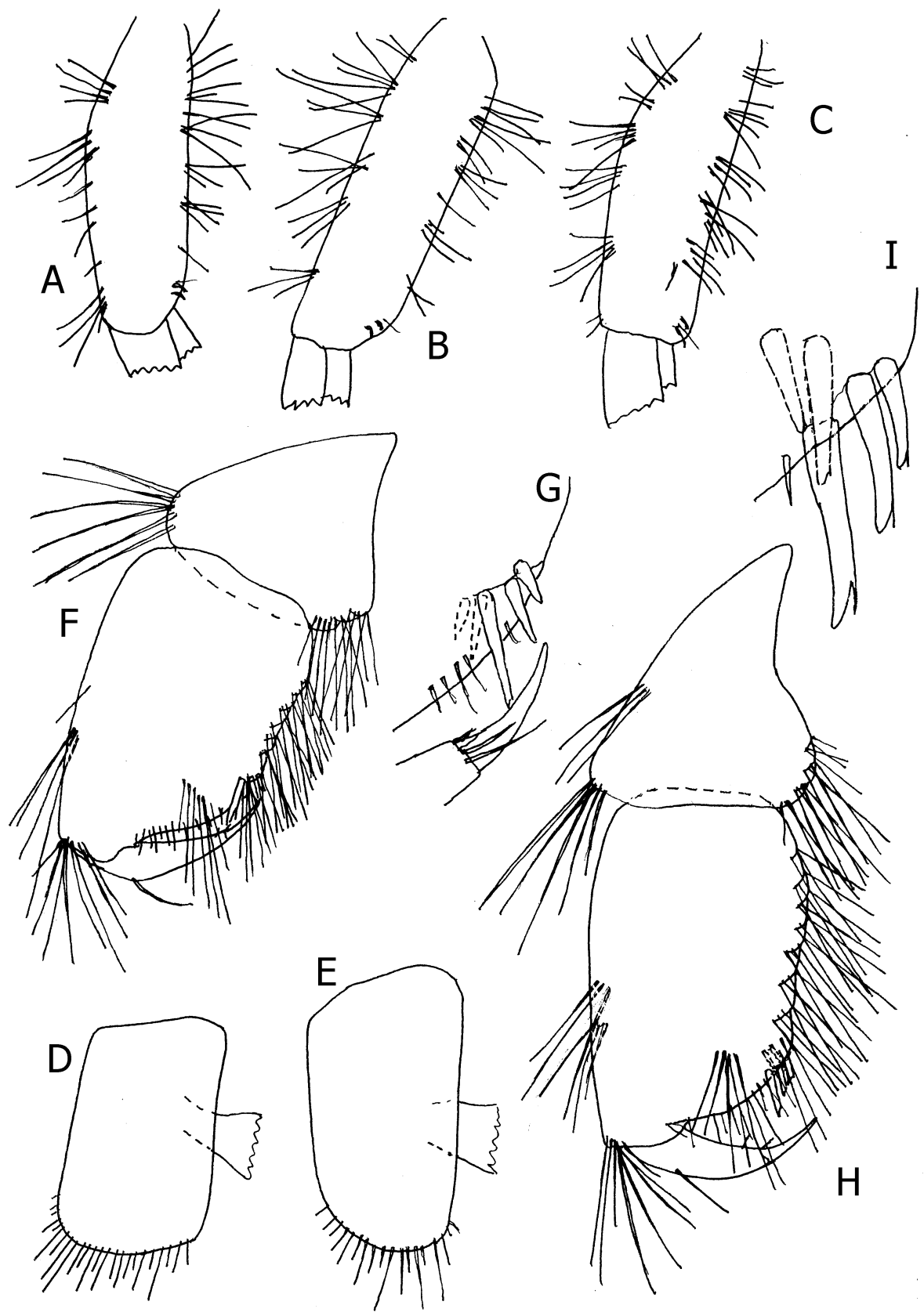

Fig. 6. Turcogammarus spandli (S. Karaman, 1931), torrent near Hilandar Monastery, male $12.8 \mathrm{~mm}$ : $\mathrm{A}=$ pleopod $1 ; \mathrm{B}=$ pleopod $2 ; \mathrm{C}=$ pleopod 3 .

Female 8.6 mm: $\mathrm{D}=\operatorname{coxa} 1 ; \mathrm{E}=\operatorname{coxa} 2 ; \mathrm{F}=$ gnathopod 1 , articles $5-6$, outer face; $\mathrm{G}=$ distal corner of gnathopod 1-propodus, outer face; $\mathrm{H}=$ articles 5-6 of gnathopod 2, outer face; I= distal corner of gnathopod 2-propodus, outer face. 
Pleopods 1-3 with 2 retinacula, often mixed with 1-2 setae (fig. 5G). Peduncle of all pleopods with numerous long setae along anterior and posterior margin (figs. 6A-C).

Uropod 1: peduncle longer than rami, with dorsoexternal row of 3 spines and dorsointernal row of 2 spines (fig. 1C); inner and outer ramus of equal length, provided with 1-2 lateral and 5 distal short spines.

Uropod 2: peduncle with single lateral and distal spines; inner ramus longer than outer one, with one lateral and 5 distal short spines; outer ramus with one lateral and 5 short distal spines (fig. 1C, D).

Uropod 3 biramous; peduncle longer than broad, with single distal spines; inner ramus scale-like, much shorter than peduncle, bearing 2 distal spines and 23 long setae. Outer ramus 2-articulated: first article long, much longer than peduncle (ratio: 92:41), outer and inner (mesial) margin densely covered with plumose setae, mixed on outer margin with 3 single spines (fig. 1G); second article very short, not exceeding diameter of first article and provided with distolateral plumose setae (fig. $1 \mathrm{H}$ ).

Telson slightly broader than long (ratio: 92:83), incised nearly to the basis, lobes tapering distally, with 2 distal spines mixed with several short and long setae; a pair of short plumose setae sitting subdistally at outer margin (fig. 4E).

Coxal gills moderately large, dilated, more or less ovoid, appear on gnathopod 2 and pereopods 3-7 (figs. 3D; 4B, D; 5A, B, C).

\section{FEMALE $8.6 \mathrm{~mm}$ with 22 eggs in marsupium (Hilandar)}

Body rather smaller and more stout than that in male. Mesosomal and metasomal segments like these in male. Urosomal segments 1-2 with dorsal conical tubercle bearing 2 spines mixed with several setae; urosomal segment 3 flat, on each side with dorsolateral 2-3 spines and single setae, medially with 2 setae. Urosomal segment 1 without ventroposterior spine near basis of uropod 1peduncle but with bunch of ventromarginal setae. Epimeral plates1-3 like these in male but plates 2-3 less pointed (fig. 7F).

Head and eyes like these in male. Antenna 1 remarkably shorter than half of body-length; peduncular articles 1-3 rather stout, progressively shorter (ratio: 53:27:16), articles with several setae (the longest setae reaching diameter of articles themselves) (fig. 7A), main flagellum 18-articulated, scarcely setose; accessory flagellum 3-articulated, longer than last peduncular article. Antenna 2 and mouthparts like that in male.

Coxae rather similar to these in males. Coxa 1 longer than broad (ratio: 61:40) slightly dilated distally (fig. 6D), with numerous long marginal setae. Coxa 2 longer than broad (ratio: 72:40), slightly tapering ventrally, bearing numerous long distal setae (fig. 6E). Coxa 3 longer than broad (ratio: 80:44), slightly tapering ventrally, with numerous marginal setae (fig. 8B). Coxa 4 longer than broad (ratio: 83:65), with numerous marginal setae, ventroposterior lobe well developed (fig. 8D). 


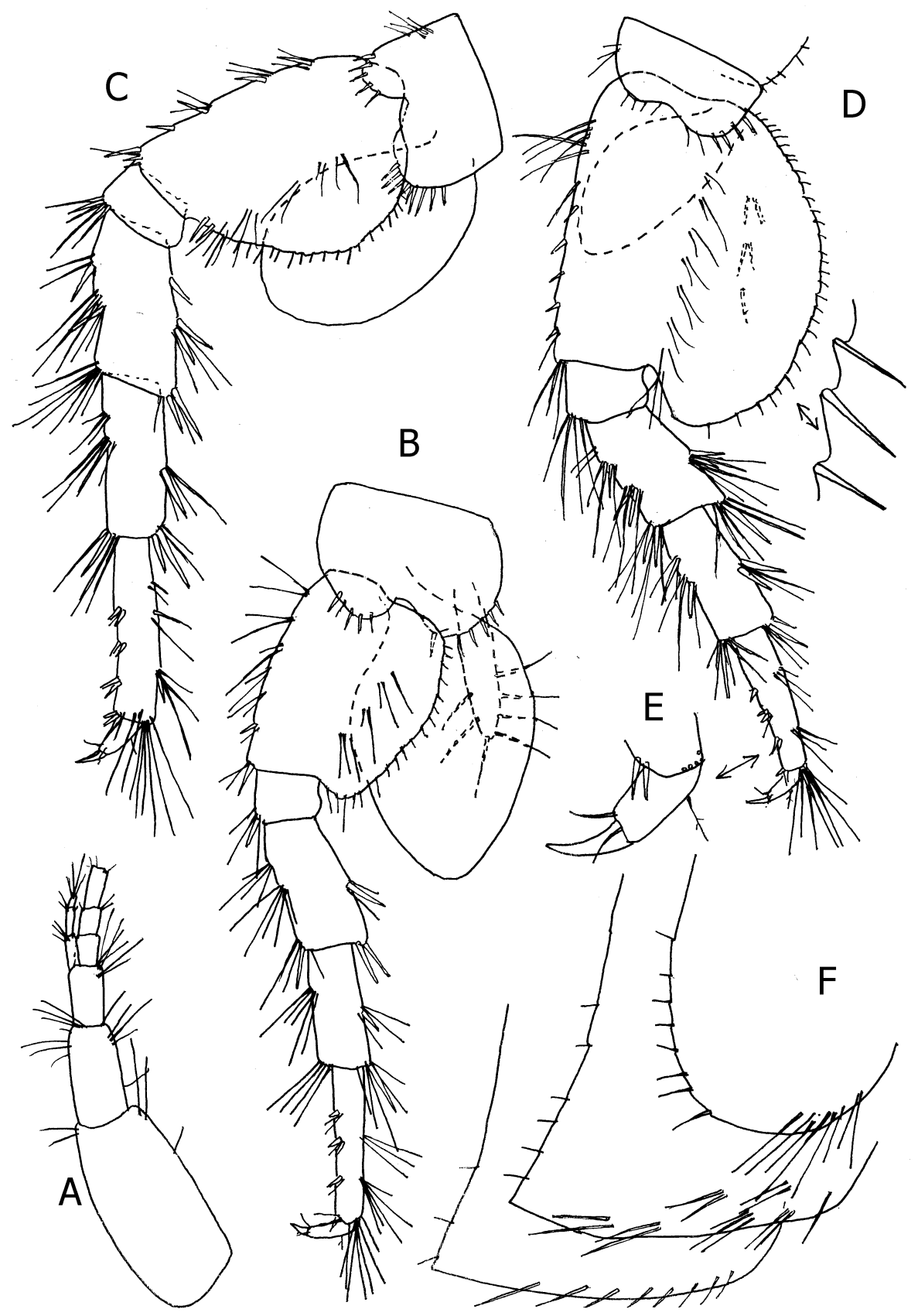

Fig. 7. Turcogammarus spandli (S. Karaman, 1931), torrent near Hilandar Monastery, female $8.6 \mathrm{~mm}: \mathrm{A}=$ antenna 1 ; $\mathrm{B}=$ pereopod 5' $\mathrm{C}=$ pereopod 6 ; $\mathrm{D}-\mathrm{E}=$ pereopod $7 ; \mathrm{F}=$ epimeral plates $1-3$. 


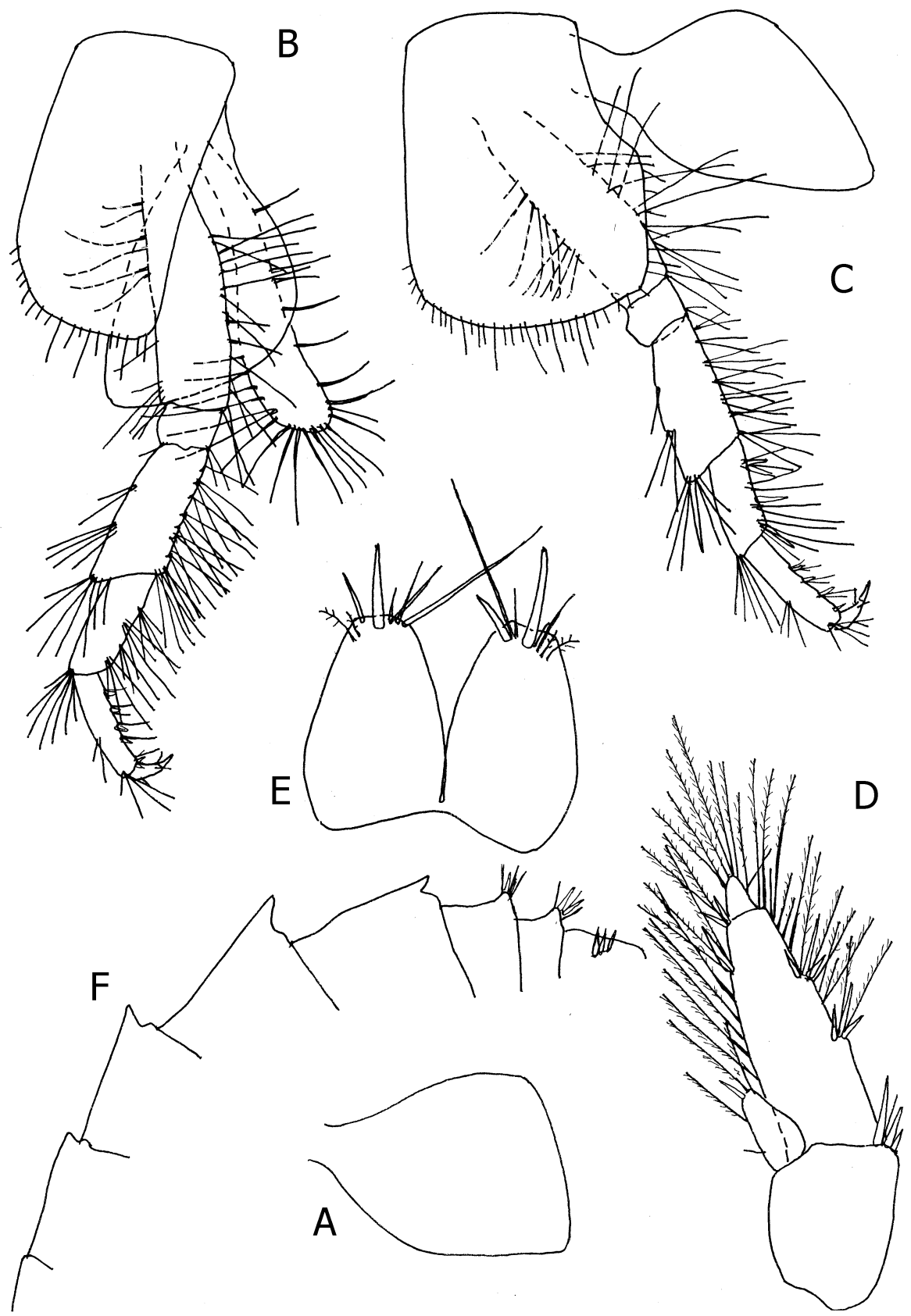

Fig. 8. Turcogammarus spandli (S. Karaman, 1931), torrent near Hilandar Monastery, female $8.6 \mathrm{~mm}: \mathrm{A}=$ gnathopod 2 gill; $\mathrm{B}=$ pereopod $3 ; \mathrm{C}=$ pereopod 4; $\mathrm{D}=\operatorname{uropod} 3 ; \mathrm{E}=$ telson. $\mathrm{F}=$ metasome and urosome of male $6 \mathbf{~ m m}$ from Drama (S-1454). 
Coxae 5-7 shallow, bilobed, lobes subrounded ventrally. Coxa 5 broader than long (ratio: 51:35), both lobes with row of marginal spine-like setae (fig. 7B). Coxa 6 broader than long (ratio: 42:30), both lobes with row of spine-like setae (fig. 7C). Coxa 7 broader than long (ratio: 41:21), both lobes with row of spine-like setae (fig. 7D).

Gnathopods dissimilar, smaller than these in male. Gnathopod 1: articles 24 like these in male; article 5 shorter than propodus (ratio: 65:85), at both margins with numerous long setae. Propodus nearly subquadrate, longer than broad (ratio: 85:57), slightly tapering distally; posterior margin with 6-7 transverse rows of setae, anterior margin with 2 median and distal group of setae (fig. 6F). Palm slightly convex, inclined nearly $1 / 3$ of propodus-length, outer face in the middle with row of 6-7 long setae (spine absent), corner with 3 unequal spines mixed with single setae (fig. 6G), inner margin with 2 unequal subcorner R-spines. Dactylus poorly exceeding posterior margin of propodus, one median seta at outer margin and 2-setae at lateral margin near basis of the nail, and one ventral marginal seta (fig. $6 \mathrm{~F}$ ).

Gnathopod 2 distinctly larger than gnathopod 1; articles 2-4 like these in males. Article 5 triangular, shorter than propodus (ratio: 80:92), both margin with numerous setae (fig. $6 \mathrm{H}$ ). Propodus more quadrate, longer than broad (ratio: 92:58), posterior margin with nearly 7 transverse rows of setae. Palm slightly convex, inclined nearly $1 / 4$ of propodus-length, outer face with median group of long setae (spine absent) and 3 strong unequal corner spines, inner face with 2 unequal subcorner R-spines (fig. 6 I). Dactylus poorly exceeding width of propodus, outer margin with one median seta, inner margin with 2 setae near basis of the nail and one short marginal seta (fig. $6 \mathrm{H}$ ).

Pereopods 3-4 stout. Pereopod 3: both margins of article 2 with long setae; articles 4-6 of different length (ratio: 40:30:30); articles 4-5 posterior margin with several bunches of setae longer than diameter of articles themselves, anterior margin with 3 bunches (article 4) or one bunch of long setae (article 5). Article 6 posterior margin with 6 short single spines mixed with single longer setae (fig. 8B). Dactylus shorter than article 6 (ratio: 18:29), inner margin with one strong seta, like that in male, and one lateral seta near basis of nail.

Pereopod 4 pilosity and dactylus like that in pereopod 3. Articles 4-6 of different length (ratio: 39:26:30) (fig. 8C).

Pereopod 5: pilosity like that in male; article 2 short, longer than broad (ratio: 57:45), anterior margin with several groups of shorter setae, posterior convex crenulated margin with numerous short setae, inner face with several groups of setae, outer face without facial setae; ventroposterior lobe developed (fig. 7B). Articles 4-6 of different length (ratio: 36:34:43); anterior margin of articles 4-5 with 4 groups of long setae mixed with single stronger spines, posterior margin with 2 groups of strong spines mixed with single longer setae. Article 6 anterior margin with 4 groups of 1-2 short spines, posterior margin with 3 bunches of long setae. Article 2 longer than article 6 (ratio: 57:43). Dactylus 
much shorter than article 6 (ratio: 18:43), with one longer seta at inner margin and one lateral seta near basis of nail.

Pereopod 6: article 2 longer than broad (ratio: 75:52), tapering ventrally, without lobe; anterior margin with 5 single spines mixed with 1-3 short setae, posterior convex crenulated margin with numerous marginal setae, on face appear several groups of setae (fig. 7C). Articles 4-6 of different length (ratio: 45:43:49). Articles 4-5 at both margins with bunches of long setae mixed with single strong spines; article 6 anterior margin with 4 groups of short spines, posterior margin with 4 bunches of long setae and 1-2 spines. Article 2 longer than article 6 (ratio: 75:49). Dactylus shorter than article 6 (ratio: 21:49), inner margin with one seta and one lateral seta near basis of nail.

Pereopod 7: article 2 almost ovoid, longer than broad (ratio: 87:70), with well developed ventroposterior lobe, anterior margin with row of single spines mixed with single short setae, posterior crenulated margin with numerous shorter setae, both faces with several bunches of setae (fig. 7D); articles 4-6 nearly of similar length (ratio: 38:37:38); articles 4-5 at anterior and posterior margin with single strong spines mixed with bunches of long setae (the longest setae exceeding diameter of articles themselves). Article 6 anterior margin with 4 groups of short spines, posterior margin with 3 groups of long setae. Article 2 longer than article 6 (ratio: 70:38). Dactylus much shorter than article 6 (ratio: 19:38), inner margin with one seta and one lateral seta near basis of the nail (fig. 7E), nail shorter than pedestal (ratio: 22:30).

Pleopods 1-3 with 2 retinacula, pilosity of peduncles like that in male.

Uropods 1-2 like these in male. Uropod 3 shorter: peduncle poorly longer than broad, with 3-4 distal spines; inner ramus short, scale-like, with several lateral and distal plumose setae. Outer ramus 2-articulated: first article along both margins with numerous long plumose setae mixed with single spines (fig. 8D); second article very small, shorter than diameter of first article and provided with lateral and distal plumose setae (fig. 8D).

Telson broader than long (ratio: 75:60) incised almost to the basis; each lobe with 1-2 distal spines mixed with 4-5 unequal setae (fig. 8E); usually one distal seta is very long; a pair of short plumose setae are attached subdistally on outer margin of lobe.

Gills on gnathopod 2 and pereopods 3-6 large, more or less ovoid (figs. 7B, C; 8B, C), these of pereopod 7 rather smaller (fig. 7D).

Oostegites narrow, with long marginal setae, appear of gnathopod 2 to pereopod 5 (figs. 7B, 8B).

\section{VARIABILITY}

Accessory flagellum with 3-4 articles. The pilosity of facial and marginal setae on pereopods rather variable, but always remarkably setose. Gnathopod 1 propodus in male along posterior margin with 4-6 transverse groups of setae, palm with 3-4 corner spines on outer face, and 2 subcorner R-spines on inner face. 
Gnathopod 2 propodus along posterior margin with 8-11 transverse rows of setae; palm inclined, irregularly serrate, with one median and 3-4 corner unequal spines on outer face, and 2 subcorner R-spines on inner face.

Epimeral plates 2-3 usually more pointed in males than in females, epimeral plate 1 nearly subrounded, with more or less marked ventroposterior corner seta, plates 2-3 without distinct corner seta.

The shape of dorsal surface of body very variable: the most number of specimens from Hilandar are with moderately elevated metasomal segments 1-3 with subrounded longitudinal keel, but some specimens are with poorly developed dorsal metasomal elevation, and some specimens almost without dorsal elevation of metasomal segments. The specimens from Drama and Thessaloniki region are usually with hooked metasomal elevation, although some specimens have low metasomal elevation without hooked tip, like these from Hilandar. Only scarce number of specimens have last mesosomal and all three metasomal segments with distinct dorsomedian hooked tooth (some specimens from Drama) (fig. 8F).

Large variability of dorsal surface of mesosomal and metasomal segments in specimens of this species indicated limited validity of this morphological character as taxonomical distinguish character. The similar situation is in Gammarus roeselii Gervais 1835-complex, where also large variability of dorsal carina on last mesosomal and all three metasomal segments are present in the specimens of same or different localities (Karaman, S. \& Karaman, G., 1959). Further molecular-genetical and morphological studies, including breeding experiments of all these population, will probably help to understand the taxonomical validity of these characters in recognition of single taxa and its reproductive isolation.

Urosomal segments 1-2 in all specimens are with distinct conical dorsal elevation bearing 1-2 spines and various number of setae; urosomal segment 3 always with 2 dorsolateral groups of spines and setae, and usually 2 short median setae.

Telson with 1-2 distal spines mixed with several setae of various length.

LOCUS TYPICUS: torrent near Dervent (Thessaloniki reg., Greece).

\section{LOCALITIES CITED: GREECE:}

Karaman, S. 1931: locus typicus;

Karaman, G. 1971: Volvi Lake; Drama; spring Varvara near Drama;

Sket \& Hou 2018: Thessaloniki; Apollonias Stream near Thessaloniki; Mikri Volvi Lake; Xanthi, Stathmos, Nestos brook;

Straskraba 1967: Thessaloniki.

New localities: Torrent near Hilandar Monastery, Halkidiki peninsula, Greece.

TURCOGAMMARUS ARALENSIS (Uljanin, 1875)

Gammarus aralensis Uljanin, 1875: 2, pl. V, figs. 15-19; Sowinsky, 1894: 15, pl. 1, figs. 1-9, pl. 2, figs. 10-18; 
Obesogammarus aralensis Stock, 1974: 79, 93;

Pontogammarus aralensis Dershavin, 1912: 15; Mordukhai-Boltovskoi et al., 1969; 466, pl. XII, fig. 1;

Pontogammarus (Gammarus) aralensis Martynov, 1924: 214;

Pontogammarus cf. aralensis: Sket \& Hou, 2018, suppl. 2: 6;

Dikerogammarus aralensis Birstein, 1945: 519; Barnard, J.L., 1958: 48; Plotnikov et al., 2012 (2017): 6, 11, fig. 6; Plotnikov et al., 2021: 12 ;

Turcogammarus aralensis Barnard, J.L. \& Barnard, C.M., 1983: 170; Zonn et al., 2009: 179; Palatov, 2018: 152; Copilas-Ciocianu \& Arbaciauskas, K., 2018: 286, fig. 1F;

Dikerogammarus haemobaphes (part.) Stebbing, 1906: 459.

LOCUS TYPICUS: Among Zostera in bay Sary-chaganack, coast of Aral Lake, Kazakhstan.

LOCALITIES CITED: Regions of Black Sea, Caspian Sea, Azov Sea, Aral Sea:

Uljanski 1875: locus typicus.

Sowinsky 1894: Aral Sea, coast of southern bay of Nikolai Island. He presented various figures of this species.

Dershavin 1912: Delta of Volga River.

Martynov 1924: Don River; Aral Lake; vicinity of Rostov; Charkhal Lake (Uralsk reg.); Mouth of Volga River.

Mordukhai-Boltovskoi et al. 1969: waters of lower Don River; Aral Sea and several bays of Caspian Sea; probably also in salt lagoons and limans of Azov Sea.

Zonn et al. 2009: Balakhandsky relics in Aral paleobasin (Amudarya paleobasin, from the time of hyperhaline Balakhandsky Lake that existed 5.3-3.5 mil. years ago);

Plotnikov et al. 2012 (2017); 2021: Aral Sea (Caspian areal). They mentioned disappearance of $T$. aralensis from the Aral Sea according the disappearance of lake-water;

Copilas-Ciocianu \& Arbaciauskas, 2018: Kazakhstan: Kulsary, Zhem River [lat./longitude: 47.051/ 54.060];

Palatov 2018: lower part of Yakornaia River (Krasnodarskii region); water streams of Novy Afon (eastern Black Sea region);

Sket \& Hou 2018: Odesskaia Oblast, Katlabuh Lake, Ukraine.

TURCOGAMMARUS SETOSUS (Schâferna, 1914)

Dikerogammarus setosus Schâferna, 1914: 1-5, 2 pls.; Schellenberg,

1937: 267; Birstein, 1945: 519; Barnard, J.L., 1958: 48;

Pontogammarus setosus Martynov, 1924: 214; Barnard, J.L. \& Barnard, C.M., 1983: 170; 
Obesogammarus setosus Stock, 1974: 83.

Turcogammarus setosus Palatov, 2018: 21.

LOCUS TYPICUS: springs at mouth of river Aras near Ordubad, in area of Caspian Sea, Azerbaidzan)

\section{LOCALITIEX CITED:}

Schâferna, 1914: locus typicus.

Palatov 2018 cited it for Aralis region of Araks valley, eastern Zakavkazie.

\section{TURCOGAMMARUS TURCARUM (Stock, 1974)}

Obesogammaru turcarum Stock, 1974: 87, figs. 2-6; Ozbek, 2011: 450;

Turcogammarus turcarum Karaman, G. \& Barnard, J.L., 1979: 137;

Barnard, J.L. \& Barnard, C.M., 1983: 170; Palatov, 2018: 248 (=error: turcatum).

LOCUS TYPICUS: fountain at Little Mount Ararat, directly at the Turkish-Iranian border (Agri prov.), Turkey;

\section{LOCALITIES CITED:}

Stock 1979: locus typicus.

Palatov 2018: consider this species as relict of Kura-Araksinsk lowland (Azerbaidzan).

Ozbek 2011: Anatolia.

\section{DISCUSSION}

The genera Turcogammarus, Obesogammarus, Dikerogammarus and Pontogammarus are rather similar genera although distinct to each other. Probably just because of this fact, species belonging now to the genus Turcogammarus, have been often mentioned in different genera by various authors.

G. Karaman \& Barnard (1979) regarding problem of genera belonging now to the family Pontogammaridae and its genus Dikerogammarus Stebbing, 1899, mentioned:" To clarify this genus and Obesogammarus Stock (1974), we validate the usefulness of urosomal knobs as a generic character and remove Pontogammarus spandli S. Karaman (1931) and Obesogammarus turcarum Stock (1974) from Obesogammarus to a new genus, Turcogammarus. Dikerogammarus thus receives all other species with urosomal knobs and Obesogammarus remains free of knobbed species. The species to be relegated to Turcogammarus differ from Obesogammarus in the presence of urosomal knobs and from Dikerogammarus in the strong setosity on the anterior coxae and on article 2 of pereopods 5-7".

As most of Turcogammarus species are only partially described and for this reason seems rather similar to each other, the key to the species of this genus is only conditionally composed. 


\section{KEY TO THE SPECIES}

1. Pereopod 7 article 2 in males with very short posterior marginal setae; setae on epimeral plate 2 relatively short. (epimeral plates 2-3 sharply pointed) ARALENSIS (Uljanin, 1875)

-- Pereopod 7 article 2 in males with longer posterior marginal setae; setae on epimeral plate 2 long and more numerous ..............................................

2. Epimeral plate 2 densely setose, epimeral plate 3 scarcely setose (metasomal segments not elevated dorsally)

SETOSUS (Schäferna, 1914)

---Epimeral plate 2 only moderately setose, epimeral plate 3 with row of ventral long setae (epimeral plates 2-3 moderately pointed) 3

3. Metasomal segments more or less kieled. Tubercle on urosomal segments 1-2 with 1-2 distal spines and setae; Telson with some long distal setae mixed with spines; setation of pereopods rather shorter; epimeral plates 2-3 in males strongly acute SPANDLI (S. Karaman, 1931)

-- Metasomal segments not keeled; Tubercle on urosomal segments 1-2 with 3-4 distal spines and setae. Telson with all short setae mixed with spines; setation of pereopods rather stronger; epimeral plates in males moderately pointed TURCARUM (Stock, 1974)

\section{REFERENCES}

Barnard, J.L. 1958. Index to the Families, genera, and species of the gammaridean Amphipoda (Crustacea). - Allan Hancock Foundation Publications, Occasional Paper, 19: 1-148.

Barnard, J.L. \& Barnard, C.M. 1983. Freshwater amphipods of the World. I. Evolutionary patterns. II. Handbook and bibliography. Mt. Vernon, Virginia: Hayfield Associates, pp. XIX +849 pages, 50 figs., 7 graphs, 98 maps, 12 tables.

Birstein, J.A. 1945. Reviziia sistemi kaspijskihk Gammaridae. - Dokladi Akademii Nauk SSSR, 50 (1): 517-520.

Carausu, S., Dobreanu, E. \& Manolache, C. 1955. Amphipoda. Forme salmastre si de apa dulce. - Fauna Republicii Populare Romine, Crustacea, 4 (4): 1-410, 368 figs.

Copilaș-Ciocianu, D. \& Kęstutis Arbačiauskas, K. 2018.. First record of Dikerogammarus bispinosus Martynov, 1925 in Kazakhstan:invasive or overlooked native in the Caspian Sea basin?- BioInvasions Records 7 (3): 285-291.

Dershavin, A.N. 1912. Kaspijskie elementi v faune basseina Volgi. - Trudy Ikhtiol. Labor. Astrakhan, 2 (5): 1-26. [not seen in original].

Horton, T.; Lowry, J.; De Broyer, C.; Bellan-Santini, D.; Coleman, C.O.; Corbari, L.; Costello, M.J.; Daneliya, M.; Dauvin, J.-C.; Fišer, C.; Gasca, R.; Grabowski, M.; Guerra-García, J.M.; Hendrycks, E.; Hughes, L.; Jaume, D.; Jazdzewski, K.; Kim, Y.-H.; King, R.; Krapp-Schickel, T.; LeCroy, S.; Lörz, A.-N.; Mamos, T.; Senna, A.R.; Serejo, C.; Sket, B.; Souza-Filho, J.F.; Tandberg, A.H.; Thomas, J.D.; Thurston, M.; Vader, W.; Väinölä, R.; Vonk, R.; White, K.; Zeidler, W. 2021. World Amphipoda Database. Turcogammarus Karaman \& Barnard, 1979.http://marinespecies.org/amphipoda/aphia.php?p=taxdetails\&id=550216 on 202111-12. 
Karaman, G. 1969. XXVII. Beitrag zur Kenntnis der Amphipoden. Arten der Genera Echinogammarus Stebb. und Chaetogammarus Mart. an der jugoslawischer Adriaküste. Glasnik Republičkog zavoda za zaštitu prirode i Prirodnjačke zbirke u Titogradu, 2: 59-84, 51 figs.

Karaman, G. 1971. XXX. Beitrag zur Kenntnis der Amphipoden. Über einigen Amphipoden aus Griechenland und Kleinasien.- Acta, Musei Macedonici Scientiarum Naturalium, Skopje, 12 (2/103): 21-40, 55 figs.

Karaman, G. \& Barnard, J. L. 1979. Classificatory revisions in Gammaridean Amphipoda (Crustacea), Part 1. - Proceedings of the Biological Society of Washington, 92 (1) : 106-163.

Karaman, S. 1931 III. Beitrag zur Kenntnis der Amphipoden Jugoslaviens, sowie einiger Arten aus Griechenland.- Prirodoslovne Razprave, Ljubljana, 1: 31-66, figs.1-11, 1 pl.

Karaman, S. 1934. Weitere Beiträge zur Kenntnis griechischer SüsswasserAmphipoden.- Zoologischer Anzeiger, Leipzig, 105 (7/8): 215-219, figs. 1-2.

Karaman, S. 1953 Pontokaspijski amfipodi u fauni Jugoslavije [Pontikaspische Amphipoden der Jugoslavischen Fauna].- Acta, Musei Macedonici Scientiarum Maturalium, Skopje, 1 (2): 21-60, figs. 1-61.

Karaman, S. \& Karaman, G. 1959. Gammarus (Fluviogammarus) triacanthus Schäferna, argaeus Vavra und roeselii Gervais am Balkan. - Izdanija, Institut de Pisciculture R .P. Macedoine, Skopje, 2 (9): 183-211, 54 figs.

Martynov, A.V. 1924. O nekotorikh interesnikh formakh Malacostraca iz presnikh vod Evr. Rossii i ikh rasprostranenii. - Russ. Gidrobiologi-cheskii Zhurnal, Saratov, 3 (8-10): 210-216.

Mordukhai-Boltovskoi, F.D., Greze, I.I. \& Vassilenko, S.V. 1969. Otryad amphipody ili raznonogie- Amphipoda Latreille, 1816-17: 440-524. In: M.I.Kisseleva, F.D. Mordukhai-Boltovskoi et V.V. Murina (eds.): Opredelitel fauny Tchernogo i Azovskogo morej, pp. 1-536, Izd. Naukova Dumka.

Mordukhai-Boltovskoi, F.D. (ed). 1974. Atlas of the Aral Sea invertebrates. Pischevaya Promyshlennost, Moscow. (in Russian).

Ozbek, M. 2011. Distribution of the Ponto-Caspian Amphipods in Turkish Fresh Waters: An Overview. - Mediterranean Marine Science, 12 (2): 447-453, 2 figs.

Palatov, D.M. 2018. Reofilnyi makrozoobentos vostochnogo prichernomoria.-Moskovskii Gosudarstvennyi Universitet imeni M.B. Lomonosova, Biologicheskii fakulteta, Moskva, pp. 1-339.

Plotnikov, I.S., Aladin, N.V., Keyser, D. \& Ermakhanov, Z.K. 2012 (2017). Transformation of Aquatic Animal Biodiversity in the Aral Sea. It is not Dying, but Transforming in Accordance with Water Availability and its Salinity.- pp. 126.- https://www.researchgate.net/publication/313369289,

Plotnikov, I.S., Aladin, N.V., Mossin, J. \& Heeg, J.T. 2021. Crustacean Fauna of the Aral Sea and its Relation to Ichthyofauna During the Modern Reggression Crisis and Efforts at Restoration.- Zoological Studies 60 (25): 1-24.

Schäferna, K. 1914. Über eine neue Dikerogammarus-Art aus dem Kaukasus. - Bulletin International de l’ Academie des Sciences de Bohème, Prague, 19: 1-4 (169-173), 2 pls.

Schellenberg, A. 1937. Schlüssel und Diagnosen der dem Süsswasser-Gammarus nahestehenden Einheiten ausschliesslich der Arten des Baikalsees und Australia. Zoologischer Anzeiger, 117 (11-12): 267-280, 4 figs. 
Sket, B. \& Hou. Zh. 2018. Family Gammaridae (Crustacea: Amphipoda), mainly its Echinogammarus clade in SW Europe. Further elucidation of its phylogeny and taxonomy. Supplement 2.- Family Gammaridae (Crustacea: Amphipoda), mainly its Echinogammarus clade in SW Europe. Further elucidation of its phylogeny and taxonomy.- Acta biologica slovenica, Ljubljana 61 (1): 93-102.

Sowinsky, V. 1894. Otchet' o komandirovke v Peterburg dlya nauchnykh zanyati v Zoologicheskom Muzei Akademii Nauk. - Univ. Izvest., Kiev. 24 (7): 15-30, pls. $1-2$ [1-30].

Stebbing, T.R. 1906. Amphipoda I. Gammaridea. - Das Tierreich, Berlin, 21:1-806, 127 figs.

Stock, J.H. 1974. The systematics of certain Ponto-Caspian Gammaridae (Crustacea, Amphipoda). - Mitteilungen aus dem Hamburgischen Zoologisches Museum und Institut, 70: 75-95.

Straškraba, M. 1967. Amphipoda, pp. 202-209, in: Illies, J. (Ed.): Limnofauna Europaea. Gustav Fischer Ed., Stuttgart.

Uljanin, V.N. 1875. Rakoobrazniya (Crustacea). Crustacea du voyage de Fendtchenko au Turkestan. In: Fedchenko, A.P. (ed.). Puteshestvie v' Turkestan. Izvestiya Imperatorskago Obshchestva Lyubitelei Estestvoznaniya Antropologii i Etnografii Imperial Moskow University, iv. 2 (6, Part 3):1-63, pls. 1-13.

Zonn, I., Glantz, M., Kostianoy, A \& Kosarev, A. 2009. The Aral Sea Encyclopedia.DOI 10.1007/978-3-540-85088-5_23, Ó Springer-Verlag Berlin Heidelberg 8: 1290. 